\title{
Hedychium mechukanum (Zingiberaceae), a new species from the eastern Himalayas, India
}

\author{
M. Sabu \& V.S. Hareesh \\ Malabar Botanical Garden and Institute for Plant Sciences, \\ Olavanna, Kozhikode - 673 014, Kerala, India \\ msabu9@gmail.com
}

\begin{abstract}
The new species Hedychium mechukanum M.Sabu \& Hareesh is described from Arunachal Pradesh, India. It shows similarities to Hedychium urophyllum G.Lodd., $H$. coronarium J.Koenig, H. flavum Roxb. and H. chrysoleucum Hook. from Northeast India, and to $H$. qingchengense Z.Y.Zhu from China. A detailed description along with colour photographs are provided for ease of identification.
\end{abstract}

Keywords. Arunachal Pradesh, Northeast India, Quing, Zingiberales

\section{Introduction}

The genus Hedychium J.Koenig, established in 1783 based on the species H. coronarium J.Koenig and which is mainly distributed in tropical, subtropical and warm-temperate regions, is regarded as one of the most diverse in the family (Sirirugsa \& Larsen, 1995; Newman et al., 2004; Newman et al. (2005-); Tanaka et al., 2016; Ding et al., 2018). Many species have potential ornamental value. They are commonly known under the names "ginger lily" or "butterfly lily", due to the presence of beautiful and fragrant flowers. The genus has about 80 taxa of which 44 taxa are in India, mainly distributed in the Western Ghats and Northeast India (Sanoj, 2011). Recently, five new taxa have been published from different regions of India (Sanoj et al., 2010; Sanoj \& Sabu, 2011; Thomas et al., 2015; Odyuo \& Roy, 2017; Ashokan \& Gowda, 2019). In this article, another new species of Hedychium from Arunachal Pradesh in Northeast India, with the largest flowers of any Hedychium spp. in this region, is described. This species has large showy flowers with a pleasant fragrance and could be introduced as an ornamental plant.

\section{Materials and methods}

During recent floristic expeditions in the eastern Himalayas, from Quing and Tato, near Mechuka valley, Shi-Yomi district, Arunachal Pradesh, we observed a large, white-flowered Hedychium with a yellow patch at the centre of the labellum. Morphological and phenological information was noted in the field, herbarium and spirit samples were collected for taxonomic studies, and rhizomes were collected for 
germplasm conservation. After critical study of the relevant literature (Baker, 1892; Naik \& Panigrahi, 1961; Sirirugsa \& Larsen, 1995; Wu \& Larsen, 2000; Sanoj et al., 2010; Sanoj, 2011; Sanoj \& Sabu, 2011; Odyuo \& Roy, 2017; Ding et al., 2018), the unknown taxon was found to be similar to Hedychium urophyllum G.Lodd., $H$. coronarium, H. flavum Roxb. and H. chrysoleucum Hook. from Northeast India, and to $H$. qingchengense Z.Y.Zhu from China, but differs in the attributes summarised in Table 1. Hence, it is described here as a new species along with colour photographs and a distribution map to show the distribution of the new taxon in Arunachal Pradesh (Fig. 1).

\section{Taxonomy}

Hedychium mechukanum M.Sabu \& Hareesh, sp. nov.

The new species is morphologically similar to Hedychium urophyllum but differs from the latter in having glabrous ligules, larger flowers, labellum which is white and yellow-tinged towards the base, glabrous calyx, internally glabrous corolla tube, and longer stamens (see Table 1). - TYPE: India, Arunachal Pradesh, Shi-Yomi District, Quing, $130 \mathrm{~km}$ from Along towards Mechuka, 1450 m, 19 September 2019, M. Sabu \& V.S. Hareesh 158761 (holotype MBGH; isotype CAL). (Fig. 2).

Terrestrial perennial rhizomatous herbs. Rhizome 5-7 cm wide, creamy white internally, pale pink externally, slightly aromatic. Leafy shoot 1-2 m high, erect, robust. Leaves 12-18 in number, 4-8 cm apart, spreading, sessile or petiolate; petiole 4-7 mm long; sheath 1-1.5 cm wide, membranous, translucent, glabrous or glaucous, margins pink; ligule $1-1.2 \times$ c. $1.5 \mathrm{~cm}$, ovate, single-lobed, truncate or slightly notched at apex, glabrous, membranous, translucent, papery, closely appressed to the stem, pink; lamina 50-80 × 10-14 cm, elliptic, caudate-acuminate at apex, obtuse at base, glabrous on both sides, dark green above, pale green beneath; margin undulate, membranous, translucent, pink tinged. Inflorescence 13-18 cm long, elliptic, dense, erect. Bracts 6-7 × 3-3.5 cm, broadly-ovate, imbricate, closely appressed to flower, pale green above and white towards the base, glabrous, slightly glaucous; margin translucent, membranous, truncate at apex, cincinnus 5-flowered. Bracteoles 3.5-5 $\times$ 2-2.5 cm, ovate, membranous, translucent, tip obtuse, pale green to white, glabrous, closely appressed to flower. Flower $16.5-18 \mathrm{~cm}$ long, white with deep yellow stamen, many flowers open at a time, ascending, fragrant. Calyx $3.5-4 \mathrm{~cm}$ long, c. $2.5 \mathrm{~mm}$ wide at mouth, pale yellow, glabrous, membranous, translucent, closely appressed to corolla tube, unilaterally split up to c. $0.5 \mathrm{~cm}$, 3-toothed at tip. Corolla tube $8.5-9 \mathrm{~cm}$ long, c. $5 \mathrm{~mm}$ wide at mouth, pale yellow, white towards base, glabrous both externally and internally. Corolla lobes linear, pale yellow, membranous, drooping from corolla tube, glabrous, slightly coiled; dorsal lobe $4.8-5.3 \times 0.4-0.5 \mathrm{~cm}, \mathrm{c} .0 .5 \mathrm{~mm}$ long beak at apex; lateral lobes $3.8-4.2 \times$ c. $0.3 \mathrm{~cm}$, obtuse at apex. Lateral staminodes $6-6.5$ $\mathrm{cm}$ long, 1.8-2.2 cm long towards middle, spathulate, white, yellow tinged towards base, erect, slightly reflexed, slightly notched at apex. Labellum 7-7.5 × 6.5-7 cm, 


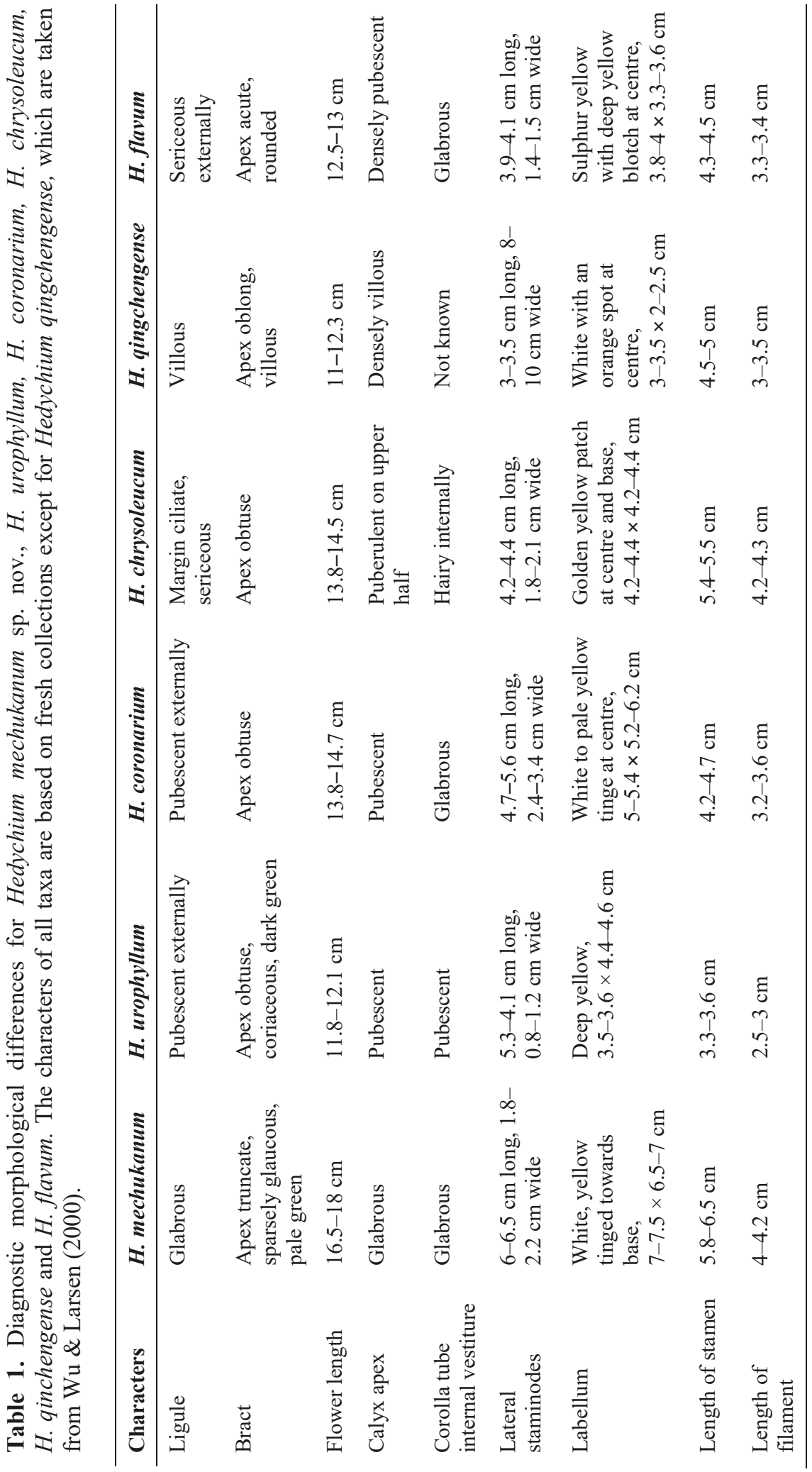




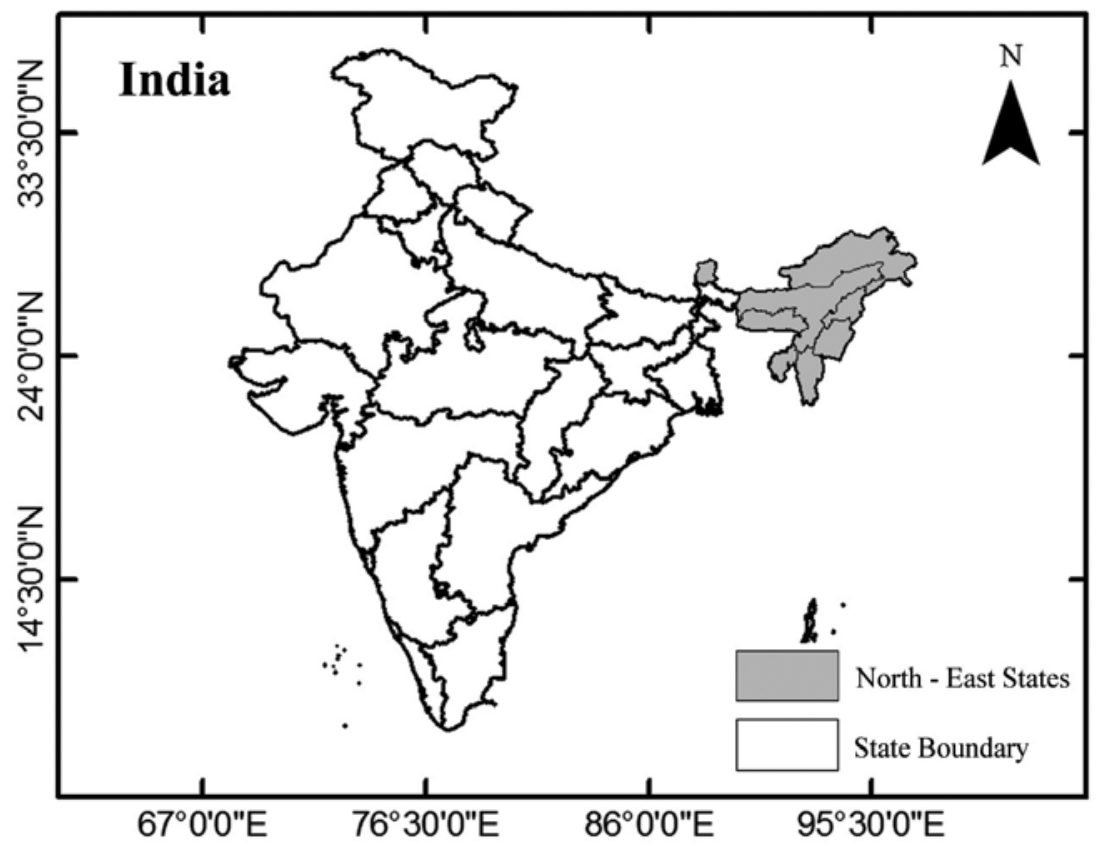

A

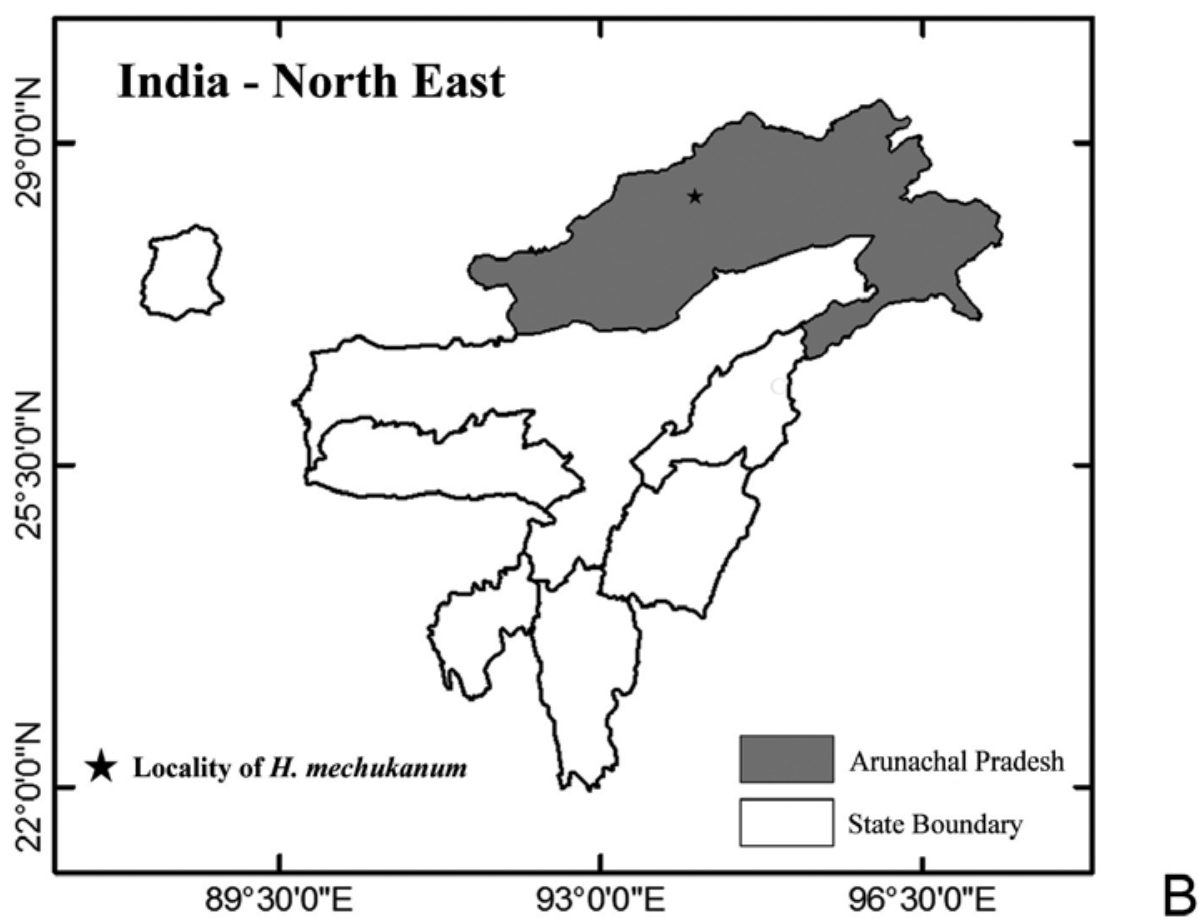

Fig. 1. Distribution map showing the collection localities of Hedychium mechukanum. A. Map of India (Northeast Indian part highlighted). B. Northeast India highlighting Arunachal Pradesh and the asterisk indicates the collection locality. 

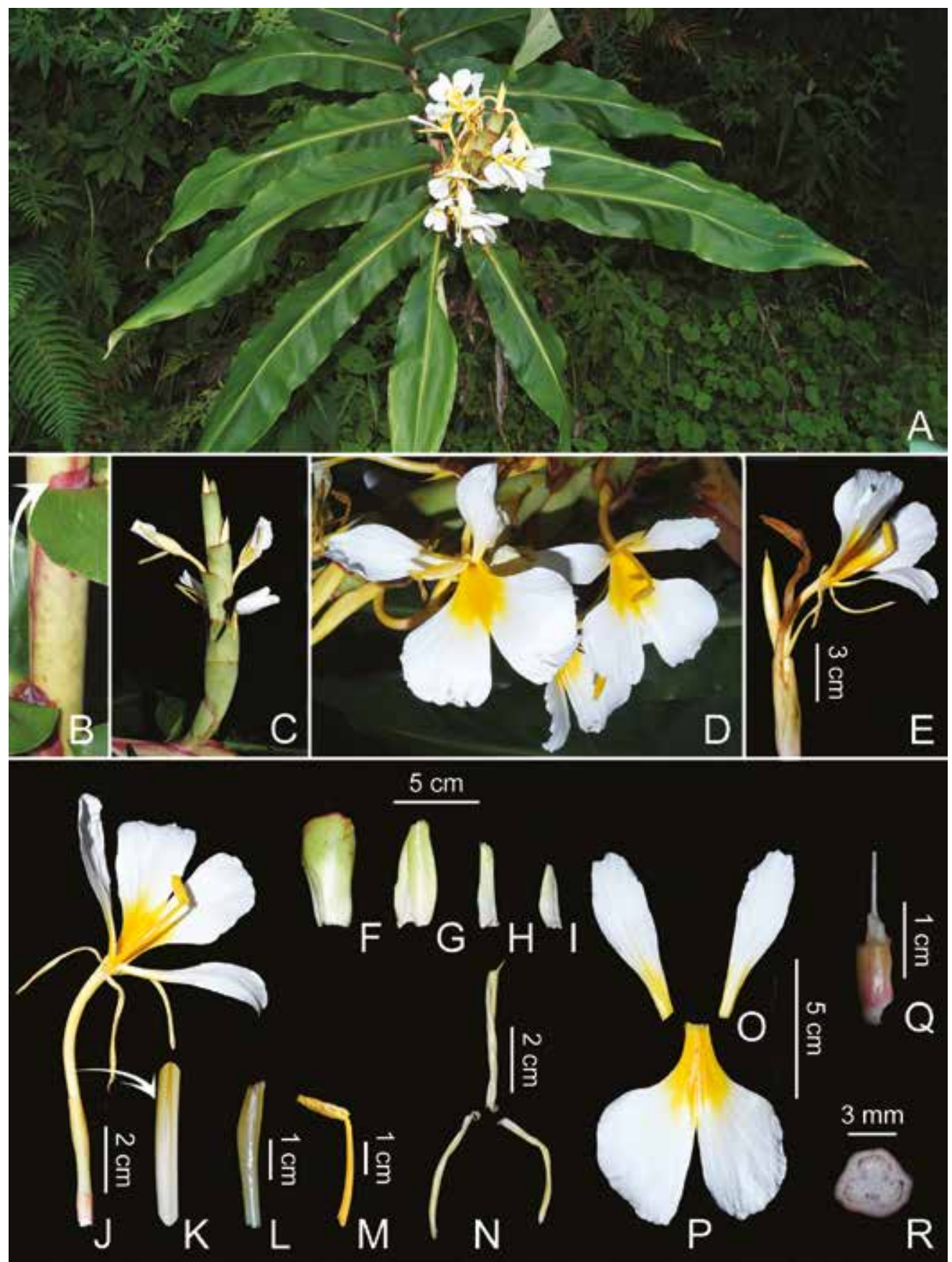

Fig. 2. Hedychium mechukanum M.Sabu \& Hareesh. A. Habit. B. Leafy shoot, arrow mark indicating ligule. C. Young inflorescence. D. Close-up of flower. E. Cincinnus with bract removed. F. Bract. G-I. Bracteoles. J. Single flower. K. Corolla tube split open. L. Calyx. M. Stamen. N. Corolla lobes. O. Lateral staminodes. P. Labellum. Q. Ovary with epigynous glands. R. Cross section of ovary. (Photos: M. Sabu and V.S. Hareesh). 
broadly ovate, white, yellow tinged towards base, erect, slightly reflexed on upper half, gradually clawed towards base; claw $1.8-2.3 \times$ c. $1 \mathrm{~cm}$; sinus $3.5-4 \mathrm{~mm}$ deep; lobes obtuse at apex. Stamen 5.8-6.5 cm long, erect. Filament $4-4.2 \mathrm{~cm}$ long, c. $4 \mathrm{~mm}$ wide at base, straight, deep yellow. Anther $1.8-2 \times$ c. $0.5 \mathrm{~cm}$, oblong, yellow, curved back, split open from top to bottom, thecae axis parallel to the filament; connective yellow, glabrous, truncate at apex. Ovary 7-9 $\times 5-6 \mathrm{~mm}$, barrel-shaped, pale pinkish yellow, sparsely puberulent externally. Style filiform, white, glabrous. Stigma c. $3 \mathrm{~mm}$ wide, yellow, cup-shaped, stigmatic head hairy. Epigynous glands two, fused towards base, 3-4 mm long, oblong, white.

Distribution. Only known from Quing and Tato near Mechuka Valley, Shi-Yomi District of Arunachal Pradesh at an altitude of around $1400 \mathrm{~m}$.

Ecology and phenology. It grows in open areas of evergreen forest in association with Musa aurantiaca G.Mann ex Baker, Musa puspanjaliae Gogoi \& Häkkinen, Ophiorrhiza rosea Hook.f., Artemisia sp., Pouzolzia sp. and Rubus sp., etc. Flowering mid-June to September, fruiting September to November.

Etymology. The specific epithet of the new taxon comes from the name of a small town, Mechuka, which borders China at about $1850 \mathrm{~m}$ above sea level in Shi-Yomi District of Arunachal Pradesh. This taxon was collected from the Mechuka valley on the way to Mechuka from Along.

Provisional IUCN conservation assessment. The type locality is along the road to Mechuka from Along. The area is under threat due to road widening. However, as this species is known only from the type locality and could be more widespread in areas away from the road and in the wider region, we assess it as Data Deficient (DD) following the IUCN guidelines (IUCN Standards and Petitions Subcommittee, 2017).

Additional specimens examined. INDIA: Arunachal Pradesh: Shi-Yomi District, Tato, 1400 m, 19 September 2019, Sabu \& Hareesh 158762 (CATH, MBGH).

ACKNOWLEDGEMENTS. The authors are grateful to the Arunachal Pradesh Forest Department for granting permission and providing necessary assistance with field studies in the forest; Herbarium curators of ARUN and CAL for the various assistance. Thanks are also due to the Mr Sathyanarayanan Mundayur, Lohit Youth Library Network, Roing; Dr K. Haridasan, Retired Scientist SFRI; Dr B.B. Bhat, Senior Scientist, Itanagar; Mr Etalo, Itanagar; Yomphy Lollen, Yinkiong and Mr Tripur, Daporijo, for assistance rendered during our expeditions. The Department of Science and Technology (New Delhi) is acknowledged for financial assistance for the research project (Sanction No. SERB/SB/SO/PS/92/2013, dtd.09.07.2014). VSH is grateful to the International Association for Plant Taxonomy for the 'IAPT Research Grant 2017'. The first author is thankful to CSIR for awarding the CSIR Emeritus Scientist post at the Malabar Botanical Garden and the Institute for Plant Sciences, Kozhikode, Kerala, India. 


\section{References}

Ashokan, A. \& Gowda, V. (2019). Hedychium ziroense (Zingiberaceae), a new species of ginger lily from Northeast India. PhytoKeys 117: 73-84.

Baker, J.G. (1892). Hedychium Koenig. In: Hooker, J.D. (ed.) Flora of British India, vol. 6, pp. 225-233. London: L. Reeve \& Co.

Ding, H.B., Yang, B., Zhou, S.S., Li, R., Maw, M.B., Kyaw, W.M. \& Tan, Y.H. (2018). Hedychium putaoense (Zingiberaceae), a new species from Putao, Kachin State, Northern Myanmar. PhytoKeys 94: 51-57.

IUCN Standards and Petitions Subcommittee (2017). Guidelines for using the IUCN Red List Categories and Criteria. Version 13. Prepared by the Standards and Petitions Subcommittee.

Koenig, J.G. (1783). Descriptions Monandrum pro annis. In: Retzius, A.J. (ed.) Observationes Botanicae, vol. 3, pp. 45-76. Lipsiae: Siegfried Lebrecht Crusium.

Naik, V.N. \& Panigrahi, G. (1961). Genus Hedychium in Eastern India. Bull. Bot. Surv. India 3(1): 67-73.

Newman, M. et al. (2005-). Zingiberaceae Resource Centre. Online database available from https://padme.rbge.org.uk/ZRC/. Accessed 3 Mar 2020.

Newman, M., Lhuillier, A. \& Poulsen, A.D. (2004). Checklist of the Zingiberaceae of Malesia. Leiden: Nationaal Herbarium Nederland, Universiteit Leiden.

Odyuo, N. \& Roy, D.K. (2017). Hedychium chingmeianum (Zingiberaceae), a new species from Nagaland, India. Telopea 20: 193-199.

Sanoj, E. (2011). Taxonomic Revision of the Genus Hedychium J. Koenig (Zingiberaceae) in India. PhD Thesis, University of Calicut, Kerala.

Sanoj, E. \& Sabu, M. (2011). The identity of Hedychium marginatum C.B.Clarke(Zingiberaceae), and a new species, H. nagamiense from North-eastern India. Bangladesh J. Pl. Taxon. 18(2): 169-176.

Sanoj, E., Sabu, M. \& Kumar, T.R. (2010). Hedychium forrestii (Zingiberaceae) with a new synonymy and a variety from India. J. Bot. Res. Inst. Texas 4: 633-639.

Sirirugsa, P. \& Larsen, K. (1995). The genus Hedychium (Zingiberaceae) in Thailand. Nordic J. Bot. 15(3): 301-304.

Tanaka, N., Ohi-Toma, T., Aung, M.M. \& Murata, J. (2016). Systematic notes on the genus Hedychium (Zingiberaceae) in Myanmar. Bull. Natl. Mus. Nat. Sci., Tokyo, B. 42(2): 57-66.

Thomas, S., Mani, B. \& Britto, S.J. (2015). A new species of Hedychium (Zingiberaceae) from the southern Western Ghats, India. Webbia 70(2): 221-225.

Wu, T.L. \& Larsen, K. (2000). Zingiberaceae. In: Wu, Z.Y. \& Raven, P.H. (eds) Flora of China, vol. 24, pp. 327-377. Beijing: Science Press; and St Louis: Missouri Botanical Garden Press. 
